\title{
Growth and Behavioural Development in Thamnomys dolichurus
}

\author{
K. PANAGIS \& J. A. J. NEL
}

\begin{abstract}
Panagis K. \& Nel J. A. J., 1981: Growth and behavioural development in Thamnomys dolichurus. Acta theriol., 26, 25: 381-392 [With 2 Tables \& 4 Figs.].

Growth and behavioural development of three litters of Thamnomys dolichurus (Rodentia, Muridae) born in captivity are described. Young are precocial (toes are separated at birth and the grasp reflex is present) and development, both physical and behavioural, is rapid, probably as a primary adaptation to an arboreal lifestyle.
\end{abstract}

[Mammal Res. Inst., Univ. of Pretoria, Pretoria 0002, South Africa]

\section{INTRODUCTION}

The genus Thamnomys is one of the few primarily arboreal murid rodents in Africa. The relationships between the members of this genus are still poorly understood; four species are recognized by Misonne (1974). Of these, T. dolichurus is widespread and occurs in southern and northern savanna woodland and forest fringes, from Port Elizabeth on the southern seaboard of South Africa northwards into tropical Africa, to Guinea-Bissau, Mali and the southern Sudan.

Although widespread $T$. dolichurus is not usually trapped in any numbers and consequently published data on this species, and others in the genus, are limited. The only study of note is that of GenestVillard (1972) on the ecology and ethology of T. rutilans, which is difficult to separate from T. dolichurus (Misonne, 1974) although they seem to be ecologically separated through habitat preference in zones of overlap. T. dolichurus is nocturnal and purely vegetarian (Hanney, 1965) and constructs spherical nests of leaves or grass some $0.6-3.0 \mathrm{~m}$ above ground, although it also utilizes nests of birds, e.g., golden weavers (Hanney, 1965).

The present paper details some adaptations in breeding and postnatal development to an arboreal life in the African tree or thicket rat $T$. dolichurus which is closely related to $T$. rutilans. The adaptations shown, e.g., precocial young and rapid development, are perhaps common to all species of this genus. 


\section{MATERIAL AND METHODS}

Test animals $\left(90^{x} 0^{x}, 8 \%\right.$ \% $)$ originated from the Ngoye forest, Eshowe district $\left(28^{\circ} 50^{\prime} \mathrm{S} 31^{\circ} 42^{\prime} \mathrm{E}\right)$ along the Natal coast of South Africa. Measurements are given in Table 1 . In the laboratory they were separated into seven pairs and placed in four large cages and three smaller ones $(102 \times 60 \times 102 \mathrm{~cm} ; 102 \times 52 \times 62 \mathrm{~cm}$ and $190 \times 50 \times 38 \mathrm{~cm}$ respectively). No attempt was made to control the temperature or the humidity. The large cages $(1.56 \times 1.23 \times 1.83 \mathrm{~m})$ had one side with one-way giass panels to permit observations. Empty 5.5 litre paint cans for nest chambers were placed at ground level or $0.5,1.0$ and $1.5 \mathrm{~m}$ from the floor in each cage. Branches extended from the entrance of each nest box to the ground. Saw-dust, $1 \mathrm{~cm}$ deep, covered the floor of the cages. All the indivduals were provided with nesting material, consisting of paper strips and dry grass. Food and water was provided ad lib. Food consisted of sunflower seeds, rat pellets, fruit, greens as well as wheat germ meal.

Post-natal development: The young were measured from the day of birth (day 0 ) at 2-day intervals, for 40 days. Tail measurements were taken from the tail tip to anus. Mass was measured to one-decimal.

Table 1

Measurements (in $\mathrm{mm}$ ) of 14 adult T. dolichurus from Ngoye forest, Natal.

\begin{tabular}{llllll}
\hline & Head and body & \multicolumn{1}{c}{ Tail } & Hindfoot & Ear & Mass $(\mathrm{g})$ \\
\hline Mean $(\overline{\mathrm{x}})$ & 127.3 & 190.4 & 23.8 & 16.6 & 67.9 \\
Range & $118-132$ & $184-201$ & $21-26$ & $15-17$ & $53.4-84.1$ \\
\hline
\end{tabular}

Behavioural observations were also carried out at 2-day intervals and the emergence of reflex actions (Fox, 1965) was noted.

Righting reflex: Young were placed on their backs and the method and the speed of righting was noted.

Grasp reflex: The fore and hindfeet were stroked with a blunt instrument and the grasp of the foot noted.

Rooting: Bi-lateral stimulation of the face was carried out and reaction noted.

Negative geotaxis: The pup was placed head down on a $45^{\circ}$ slope and its reaction noted.

Cliff-drop aversion: The pup was placed on a table top with the fore-paws and the face over the edge, and its reaction noted.

Auricular startle response: A loud noise was made by a sudden tap on the desk with a pencil, and the response noted.

Climbing ability was tested on branches of different diameter, smooth pipes, and varying thicknesses of wire placed at different angles.

\section{RESULTS}

The main reproductive period of $T$. dolichurus apparently extends from December to June, with a peak between February and May (Han- 
ney, 1965). Eight young in three litters were born in captivity during the study from February to December 1979. Litter size ranged from 1 to 4 , with a mean of 2.7 and with a sex ratio of 0.6 males/female. Hanney (1935) gave a mean litter size or number of embryos of 4.6 (range $4-6$ ). Misonne (1974) stated that litter size varies from 2-5, while Bland (1973) found that it varied from 1-7.

Two litters were born in nests construoted at ground level, and the third in a nest at $1.5 \mathrm{~m}$. All the young were born approximately $5 \mathrm{~h}$ after dusk. The weight differences between individuals of different litter sizes, as well as the total litter weight, are given in Table 2.

In a study of Grammomys s. surdaster (relegated by Davis (1962) to a form of Thamnomys dolichurus Smuts) Bland (1973) found gestation period to be 24 days, with intervals between litters of less than 28 days being rare. In the present study the period between litters was 48 days, which approaches the period of $5-6$ weeks given by Misonne (1974). Reproductive age and gestation period could not be determined. Bland (1973) mentioned that conception first occurs before 100 days of age; while Hanney (1965) noted that females from 95-99 $\mathrm{mm}$ HB were fecund.

T. dolichurus has two inguinal pairs of mammae, and nipple-clinging occurs for the first few days of life.

\subsection{Growth}

Head-body length: The mean head-body length at birth was $40.0 \mathrm{~mm}$, $30.8 \%$ of the adult value (Figs. $1 \& 2$ ). The young are about half adult size at day 15 and $75.7 \%$ of adult size at day 40 .

Tail: Mean tail length at birth was $30.5 \mathrm{~mm}$ (Fig. 1), $16 \%$ of the adult value (Fig. 2). By day 8 the tail approximates the head-body length and represents $27.1 \%$ of the adult value. From day 8 onwards the tail is longer than the head and body. By day 40 , the tail length is $90.2 \%$ of adult value.

Hind foot: At birth the hind foot averaged $8.9 \mathrm{~mm}$ (Fig. 1) and is relatively the largest structure, soon attaining adult size. It is half adult size at approximately 5 days reaches $94.1 \%$ of adult size at 40 days (Fig. 2).

Ear: The pinna is $2.4 \mathrm{~mm}$ long at birth, approximately $14.4 \%$ of adult value, and at 20 days is approximately $50 \%$ of the adult value. At day 40 it reaches $96.9 \%$ of the adult length, $16.1 \mathrm{~mm}$ (Fig. 2).

Mass: The mean birth mass was $4.2 \mathrm{~g}(\mathrm{~N}=8)$ (i.e. $6.0 \%$ of adult value). The mean and percentage mass increment at 2-day intervals from $0-40$ 
days are plotted in Fig. 3. Growth rate increased with slight slackening prior to weaning on day 19 , this is followed by a re-acceleration of the growth rate. This trend is associated temporally with the period of weaning and reflects the transition from a decline in suckling to solid food utilization. This was also found by McDowell et al. (1930). The percentage weight increment (Fig. 3) increased rapidly from day 0 to day $4(27.1 \%)$, thereafter declining to $6.3 \%$ by day 18 . At day 49 the young are $35.8 \%$ of adult mass. The average percentage increase of adult masses are shown in Fig. 2.

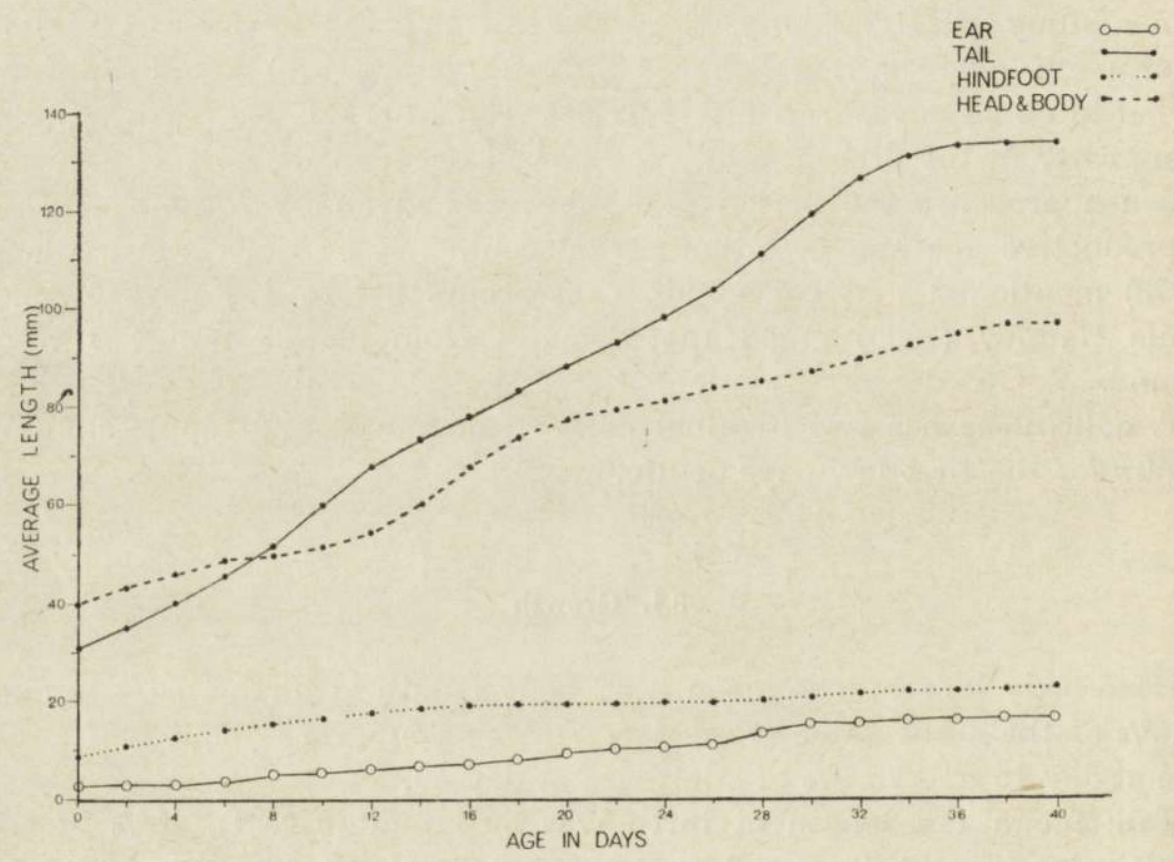

Fig. 1. Physical growth in Thamnomys dolichurus.

\subsection{Development}

The four major development stages of Thamnomys dolichurus, based on Williams \& Scott's (1953) division of the behaviour of neonatal mice, are as follows:

\subsubsection{Neonatal Period}

Period I: Birth to 6 days.

This period is identified as one in which there is mainly physical development, and with few behaviour patterns.

Physical Development: The newborn young were precocial pinkish 


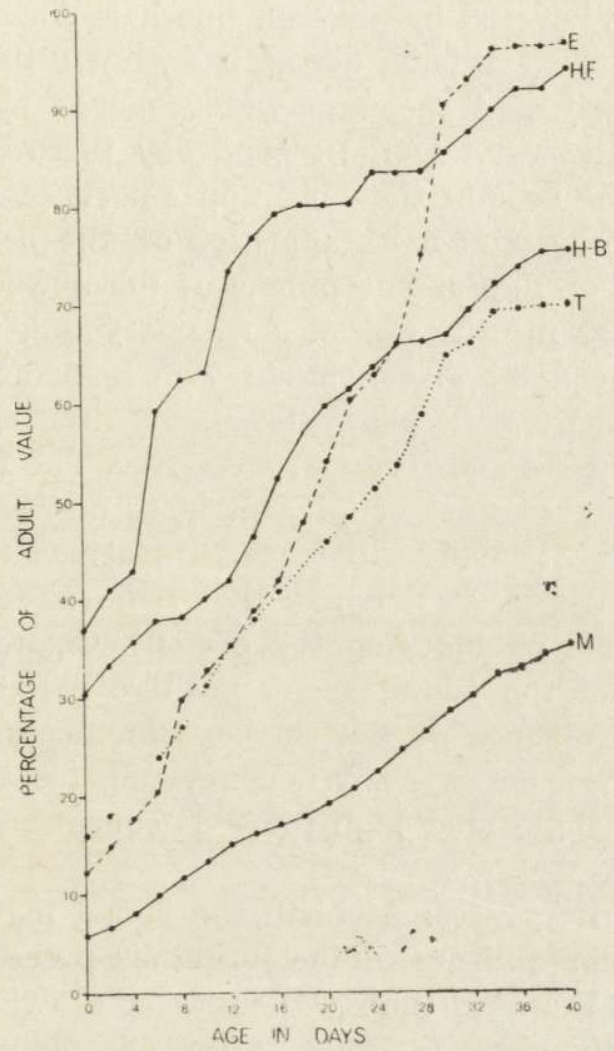

Fig. 2. Weight and linear measurement growth curves of Thamnomys dolichurus from $0-40$ days, expressed as percentages of percentages of adult values.

$\mathrm{M}=$ mass, $\mathrm{H}-\mathrm{B}=$ head-body length, $\mathrm{T}=$ tail length, $\mathrm{E}=$ ear length and H.F. $=$ hind foot length.

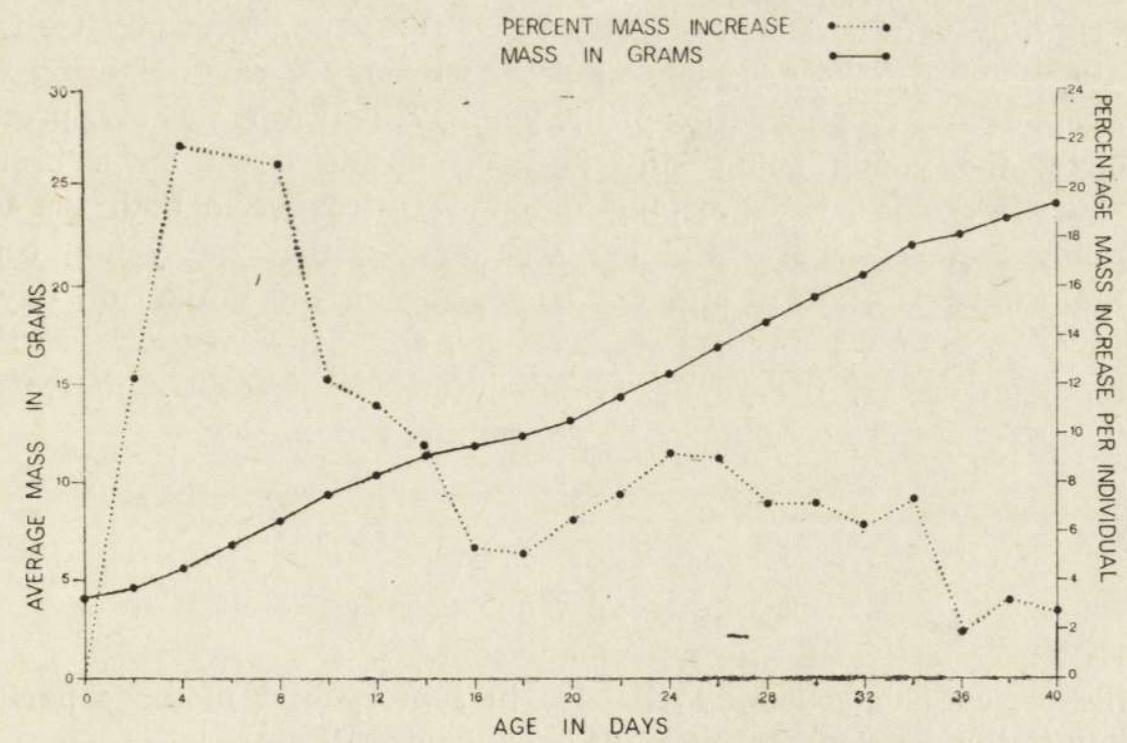

Fig. 3. Mass and percentage mass increase of young Thamnomys dolichurus born in captivity.

Acta theriol., 8 


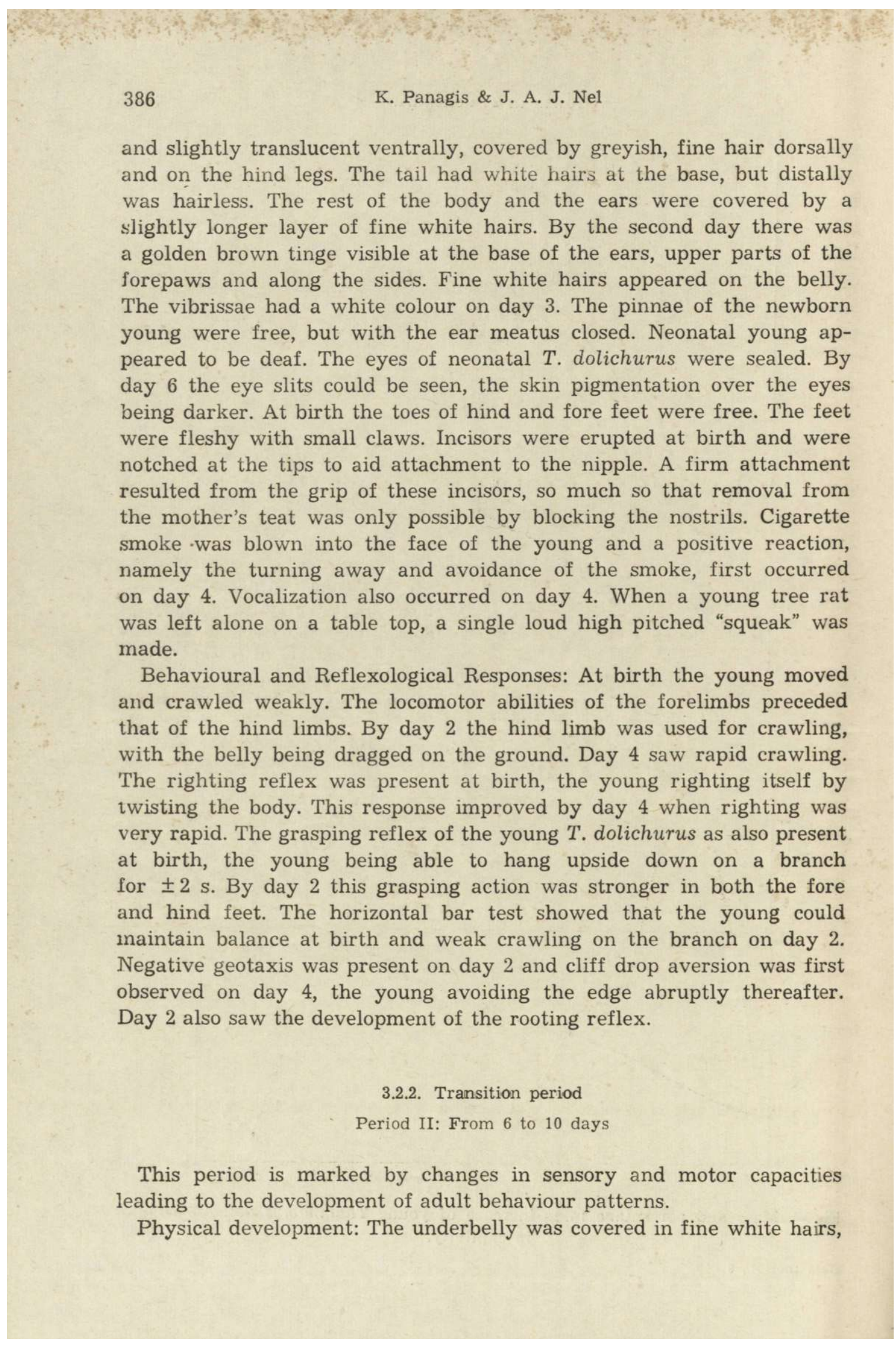


the golden tinge on the margins of the body being now more pronounced. The young were dark grey dorsally, and tail hairs appeared on day 10 . No hairs were present on the tip of the tail. The ear meatus of young $T$. dolichurus opened on day 7. By day 10 they were sensitive to sound. The eye slits could be clearly seen on day 6 and by day 10 were fully open. The young responded to visual stimuli on day 10. On day 8 they shoved a strong avoidance to smoke.

Behavioural and Reflexological Reponses: During this period movemerts were more frequent, with the hind limbs showing more coordination. The body was held off the ground. When disturbed the young crawled actively until contacting an object, against which they huddled. The young were able to crawl easily over objects placed in their paths, with the tail being slightly elevated when crawling. Strong rooting was shown at day 8 . The young still nipple-clinged during this period, and did not leave the nest. At the end of this period it seemed that all of the major sense organs were functional.

3.2.3. Socialization

Period III: From 10 to 19 days

The most significant events during this period are the opening of the eyes, at the beginning and weaning at the end.

Physical Development: The pelage of the young attained the adult appearance although it was still darker dorsally. The orange along the flanks had become prominent. The opening of the eyes at day 10 was accompanied by an increase in activity. The young $T$. dolichurus were very responsive to both tactile and vocal stimuli, with tactile hairs on the tip of the tail appearing on day 10. Abrupt sounds caused the pups to scatter and freeze. On day 14 the young frequently sniffed while crawling.

Behavioural and Reflexological Responses: The young showed defensive behaviour on day 11, by biting the handler. Self-grooming also appeared, with paw-licking and face-grooming starting on day 16 . Retrieval of the young by the female continued up to day 16 . On day 19 the young showed cliff drop aversion. During this period the young were still totally dependent on the mother. Day 15 saw the young emerge from the nest and start climbing, but never more than a few centimeters, onto a branch where they would sit motionless, rushing to the nest box at the first sign of danger. The resting periods were spent in family groups. 
This period covers the time from weaning to sexual maturity.

Physical Development: The animals reached near adult size with the testes generally becoming scrotal.

Behavioural and Reflexological Responses: The young were first observed to eat solids on day 19 , the day of weaning. The young explored the area around the nest and rapidly climbed up and down the branches to the feeding shelf. Although the eating of sunflower seed was first observed at day 23 , the young were still observed to be nipple-clinging at day 26, although not more than one at a time. Sexual behaviour, naso-anal contact between young and adults occurred on day 23 . Scratching was first observed on day 30 . Play behaviour also started during this period, the young running and climbing with their littermates. The development of reflex actions is summarized in Fig. 4.

Parent-Young Relationships: When forced to leave the nest females left with the young still clinging to the teats, although normally the young were first detached. The young generally remained upright and ran with the females if still attached to the nipples. Females also defended their young by positioning the body over them. This often occurred while attempting to remove young for examination.

Retrieval of the young by mouth-carrying was well developed and occurred often. Mouth-carrying were also observed in and described for other African rodents by e.g., Meester \& Hallett (1970). In T. dolichurus mouth-carrying involved the gripping of the loose skin on the back; the young then curled up with the tail arched over the body of the female. Pups placed outside the nest were immediately retrieved. The young when isolated gave a single loud squeak, to which the female responded. A female was observed to carry an 86 day old pup, much to its discomfort, to a nest box. This occurred a few hours before the birth of the female's subsequent litter and was perhaps due to hormonal stimulation of the carrying reponse. Females ejected adult males from the nest box for two days after the birth of the young, but from the third day onwards they were allowed to nest with the young. Progeny from previous litters were also allowed to remain within the nest box with the litter.

\section{DISCUSSION}

Several features of the breeding and postnatal development of $T$. dolichurus could have an adaptive value to an arboreal life. Indiriduals 

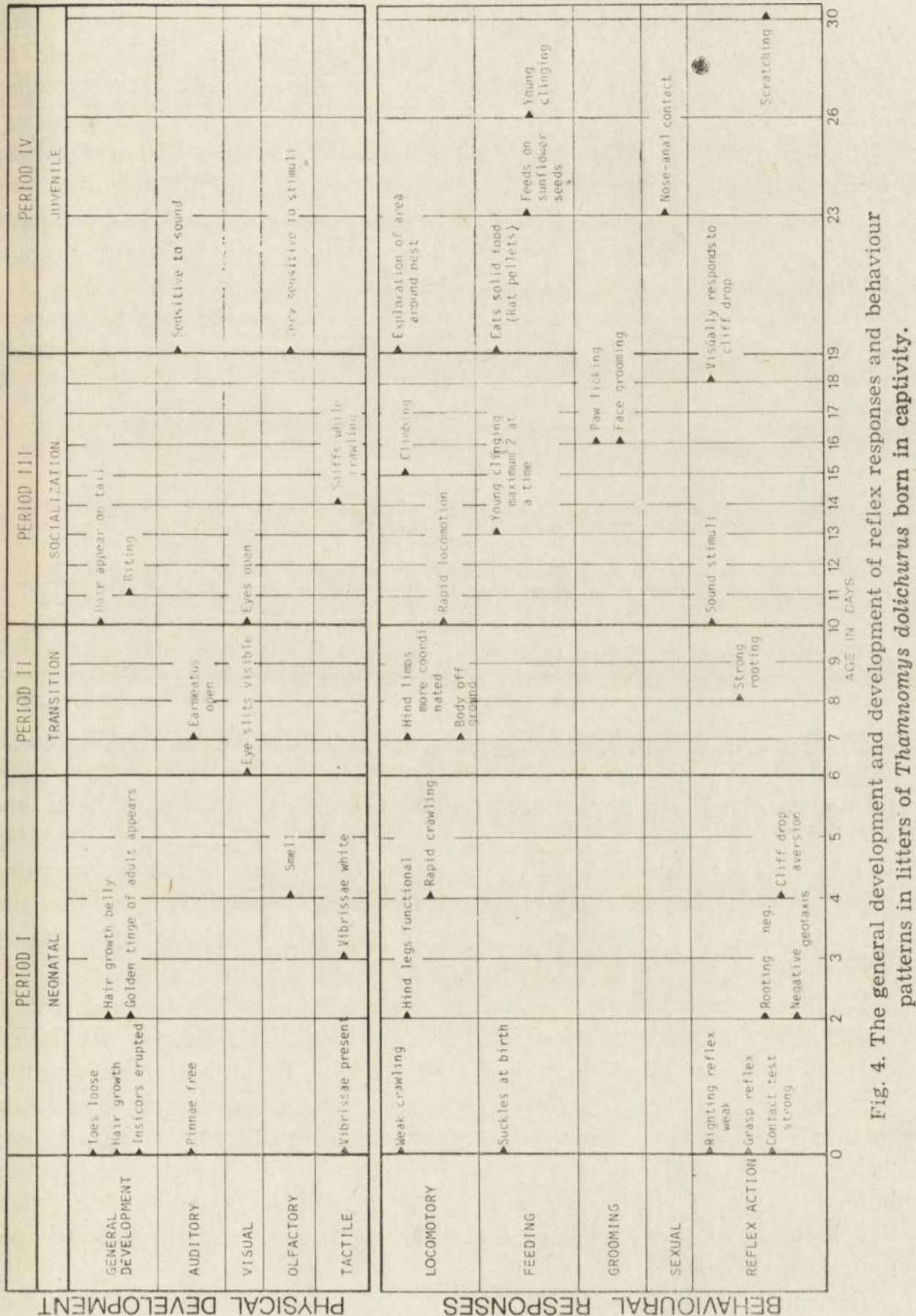
from small litters weighed more at birth (Table 2) and as only four mammae occur, larger litters would be at a disadvantage as young would not only have to compete for a nipple but also less milk would be available for each pup. A small litter would also be an advantage when nipple clinging to a female that flees when disturbed, or from predators with her young still attached. The increased group cohesion resulting from such behaviour would also tend to decrease infant mortality and enhance survival. In T. dolichurus nipple clinging is possible from birth as the incisors erupt early and have a modified structure (a central notch) to allow firm attachment to a nipple.

The accelerated physical development, shown by the toes being loose at birth and able to grasp, early ability to move around, right itself, the early opening of the eyes and ability to climb by day 15 (Fig. 4) would all contribute to increased survival and better exploitation of

Table 2

Total and average litter mass for T. dolichurus.

\begin{tabular}{ccrr}
\hline Litter size & 1 & \multicolumn{1}{c}{3} & \multicolumn{1}{c}{4} \\
\hline Total mass (g) & 4.8 & 12.0 & 15.2 \\
Mean mass (g) & - & 4.0 & 3.8 \\
\hline
\end{tabular}

the arboreal habitat at an early age. The young of $T$. dolichurus possess four of the five attributes considered as precocial, as well as being part of a group of fast developing rodents (Scott, 1979). Apart from one species, T. dolichurus shows an earlier opening of the eyes compared to any of the 16 species studied by Scott (1979). This has adaptive value especially in arboreal rodents, as it allows early mobility (possible also through the early development of physical attributes) and exploratory behaviour, as well as benefitting escape should the need arise.

Weaning also takes place at a very early age in T. dolichurus, at 19 days compared to 26 and 28-31 days in two other nipple-clingers Aethonys chrysophilus and Thallomys paedulcus (Brooks, 1972). Although wearing occurs early, allowing greater freedom to the young and the possibiity to survive should the female die, nipple-clinging can continue up to day 26 and the young remain long in the nest allowing greater maturation before leaving. The other alternative would be exceptionally sow development of the young, as found by Hamilton (1962) in the red tree mouse.

It seems probable that the small litter size, well-developed young at birth, accelerated development and relative short period to weaning are 
all adaptations in T. dolichurus to an arboreal life. In these it is similar to $T$. rutilans, as found by Genest-Villard (1972).

Acknowledgements: We thank Mrs. Susan Viljoen for donating the test animals, and the South African Council for Scientific and Industrial Research for a bursary to Panagis.

\section{REFERENCES}

1. Bland K. P., 1973: Reproduction in the female African tree rat (Grammomys sudaster). J. Zool., Lond., 171: 167-175.

2 Brooks P. M., 1972: Post-natal development of the African bush rat, Aethomys chrysophilus. Zool. Afr., 7: 85-102.

3. Davis D. H. S., 1962: Distribution patterns of southern African Muridae, with notes on some of their fossil antecedents. Ann. Cape Prov. Mus., 11: 56-76.

4 Delany M. J., 1971: The biology of small rodents in Mayanja Forest, Uganda. J. Zool., Lond., 165: 85-129.

5. Fox M. W., 1965: Reflex-ontogeny and behavioural development of the mouse. Anim. Behav., 13: 234-241.

6. Genest-Villard H., 1972: Contribution a l'ecologie et l'ethologie d'un petit rongeur arboricole, Thamnomys rutilans, en Republique Centrafricaine. Mammalia, 36: 543-578.

7. Hamilton W. J. III, 1962: Reproductive adaptation of the red tree mouse. J. Mammal., 43: 486-504.

8. Hanney P., 1965: The muridae of Malawi (Africa: Nyasaland). J. Zool. Lond., 146: $577-633$.

9. McDowell E. C., Gates W. H. \& McDowell C. J. 1930: The influence of the quantity of nutrition upon the growth of the suckling mouse. J. Gen. Physiol., 13: $529-546$.

10. Meester J. \& Hallett A. F., 1970: Notes on early post-natal development in certain southern African Muridae and Cricetidae. J. Mammal., 51: 703-711.

11. Misonne X., 1974: Rodentia. Part 6. [In: Meester, J. \& H. W. Setzer (eds). "The Mammals of Africa: An identification Manual"]. Smithsonian Press, Washington, D.C.

12. Scott E. D., 1979: A comparison of postnatal development in South African Myomorph rodents. M.S.C. thesis, Univ. of Natal.

13. Williams E. \& Scott J .P., 1953: The development of social behaviour patterns in the mouse, in relation to natural periods. Behaviour, 6: 35-64.

Accepted, February 20, 1981.

K. PANAGIS i J. A. J. NEL

\section{WZROST I ROZWOJ BEHAWIORALNY U THAMNOMYS DOLICHURUS}

\section{Streszczenie}

Opisano wzrost i rozwój behawioralny u trzech miotów Thamnomys dolichurus (Rodentia, Muridae) urodzonych $\mathrm{w}$ niewoli. Mioty te składały się $\mathrm{z} 1,3$ i 4 młodych (Tabela 2). Pomiarów dokonywano od dnia urodzenia, w dwudniowych 
odstępach, przez 40 dni (Ryc. 1, 2). Ciężar ciała zapisywano z dokładnością do 0,1 g. (Ryc. 3). Obserwacje behawioralne robiono także co 2 dni. Obejmowały one: odruchy właściwe, odruchy chwytne, grzebanie, geotaktyzm ujemny i reakcję na sygnały dźwiękowe (Ryc. 4). Młode w chwili urodzenia są dobrze rozwinięte palce mają już rozdzielone i mają prawidłowe odruchy. Dalszy rozwój, tak fizyczny, jak i behawioralny następuje u nich gwałtownie. Jest to prawdopodobnie adaptacja do nadrzewnego trybu życia. 